\title{
Determination of phenolic profile by HPLC-ESI-MS/MS and antibacterial activity of Eugenia platysema against mollicutes strains
}

\author{
Adrielli Tenfen ${ }^{1}$, Diogo Alexandre Siebert ${ }^{2}$, Daniel Spudeit ${ }^{2}$, Caio Maurício Mendes de Cordova ${ }^{1}$, Gustavo Amadeu \\ Micke $^{2}$, Michele Debiasi Alberton ${ }^{1 *}$ \\ ${ }^{1}$ Departamento de Ciências Farmacêuticas, Universidade Regional de Blumenau, Santa Catarina, Brazil. \\ ${ }^{2}$ Departamento de Química, Universidade Federal de Santa Catarina, Florianópolis, Santa Catarina, Brazil.
}

\begin{tabular}{l} 
ARTICLE INFO \\
\hline Article history: \\
Received on: 08/12/2016 \\
Accepted on: 11/03/2017 \\
Available online: $30 / 05 / 2017$ \\
\hline Key words: \\
Eugenia platysema, phenolic \\
compounds, antibacterial \\
activity, mollicutes.
\end{tabular}

\begin{abstract}
This study evaluated the phenolic composition of the extract and fractions from E. platysema leaves, in addition to antibacterial activity against different types of bacteria, like mollicutes and cel wall bacteria. The crude extract (CHE) was partitioned with solvents to yield fractions of different polarities (dichloromethane, ethyl acetate, butanol and water). The chemical composition of CHE and its fractions were evaluated by HPLC-LCESI-MS/MS together with 76 standard phenolic compounds. Nine known compounds were identified for the first time from this species: hydroxybenzoic- $O$-hexoside acid [1], gallocatechin [2], syringic acid [3], 4hydroxycinammic acid [4], salycilic acid [5], isoquercetin [6], isorhamnetin [7], luteolin-3'- $O$-glucuronide [8] and luteolin [9]. The evaluation of antibacterial activity was performed using the broth dilution method. The $\mathrm{CHE}$ and fractions of E. platysema were active against mollicutes strains, being the best result presented by the dichloromethane fraction against $U$. urealyticum, M. mycoides subsp. Capri and M. hominis $\left(125 \mu \mathrm{g} \mathrm{mL}^{-1}\right)$.
\end{abstract}

\section{INTRODUCTION}

Microorganisms are one of the most frequent causes of diseases, representing as a serious public health problem for a large portion of the population. The mollicutes are organisms responsible for several diseases such as pneumonia and pyelonephritis, both in humans and in animals. Some strains like Mycoplasma hominis and Ureaplasma urealyticum are a common commensal of the female genital tract and have been associated with pyelonephritis, bacterial vaginosis, cervicitis, endometritis, and postpartum septicemia. U. urealyticum is considered as the main cause of nonchlamydial, non-gonococcal urethritis, chorioamnionitis, preterm delivery, abortion, preterm birth, bacterial vaginosis and cervicitis (Amirmozafari et al., 2009; Falk et al., 2005; Naessens et al., 1989; Taylor et al., 2013). The mollicutes have the peculiarity of the fact they do not have cell walls, and contain cholesterol in the composition

\footnotetext{
* Corresponding Author

Michele Debiasi Alberton, Departamento de Ciências Farmacêuticas, Universidade Regional de Blumenau, Santa Catarina, Brazil. E-mail: michele@furb.br
}

of their cell membrane (Cordova et al., 2010). The lack of a rigid cell wall renders genital Mycoplasmas innately resistant to antimicrobial agents, such as $\beta$-lactam antibiotics and vancomycin, which act in this target.

Tetracyclines, macrolides, and quinolones are the major antibiotics used in the treatment of infections caused by mycoplasmas, however, their therapeutic efficacy may be unpredictable due to increasing resistance (Bayraktar et al., 2010). Therefore, there is an importance in researching new active compounds against these microorganisms from various sources, including natural products (Benfatti et al., 2010).

It is known that the Eugenia genus has innumerable therapeutic properties, among them are antimicrobial, antifungal, larvicide, besides to have hypotensive, diuretic, hipoglicemic, antiinflamatory, cytotoxic, antioxidant, hypoglycemic and cardio protective properties (Auricchio and Bacchi, 2003; Bag et al., 2012; Famuyiwa and Adebajo, 2012; Garmus et al., 2014; Saha et al., 2013; Victoria et al., 2012;). Many compounds have been described for the Eugenia genus, especially phenolic compounds, including the flavonoids (Baliga et al., 2011; Oliveira et al., 2014). 
These compounds are a large class within polyphenols, where there are more than 4000 structures with have important medicinal and biological activity, especially antimicrobial, antioxidant and to prevent cancer effects (Shafaghat et al., 2014).

Eugenia platysema, popularly known as "Guamirim", is a perennial tree of the Eugenia genus (Myrtaceae) native to South America (Reitz et al., 1969). There are few studies on this species related in the scientific literature. Apel et al., (2002), evaluated the chemical composition of the essential oil from leaves of $E$. platysema, which showed $\beta$-selinene (17.9\%) and alloaromadendrene $(12.6 \%)$ as major compounds. Tenfen et al., (2016) also analyzed the essential oil of E. platysema leaves and presented it as major compound the diterpene $(6-E, 10-Z)$ pseudo phytol $(65.55 \% \pm 0.81)$.

Nevertheless, this is the first study that evaluates chemically and biologically the extract and fractions of $E$. platysema. Thus, the aim of this study was to identificate the phenolic compounds presents in the crude extract and fractions of E. platysema leaves by HPLC-ESI- MS/MS and evaluate their antibacterial activities against cell wall and mollicutes strains.

\section{MATERIAL AND METHODS}

\section{Plant material}

Leaves of Eugenia platysema were collected in June 2013, in Blumenau, Santa Catarina State, Southern Brazil (2654'26.8"S; 4904'52.4" W). The sample was identified by Prof. Dr. Marcos Eduardo Guerra Sobral, (Departamento de Ciências Naturais, Universidade Federal de São João DelRey/MG) and André Luis de Gasper (Departamento de Ciências Naturais, FURB). A voucher specimen was deposited in the Herbarium Roberto Miguel Klein (FURB) under registration number 42336.

The dried and ground plant material was macerated in hydroalcoholic solution $(70 \%)$ at room temperature for 7 days. The crude extract resulting (CHE) from maceration was concentrated under reduced pressure to completely dry. After concentration, the crude extract was resuspended in water and partitioned by liquid-liquid fractionation using solvents of different polarities yielding dichloromethane (FDCM), ethyl acetate (FAE) n-butanol (FBu) and aqueous fractions (FAq).

\section{Identification of phenolic compounds by HPLC-LC-ESI- MS/MS}

The profile of crude extract, FDCM, FAE, FBu and FAq fractions were analysed by HPLC-ESI-MS/MS in LABEC/INCTCatálise at Federal University of Santa Catarina (UFSC). Analysis were conducted in an Agilent® 1200 chromatograph, with TurbolonSpray $^{\circledR}$ as ionization source, coupled to a Qtrap ${ }^{\circledR} 3200$ mass spectrometer, with a Phenomenex ${ }^{\circledR}$ Synergi $4 \mu$ Polar-RP 80A (150 $\mathrm{mm} \times 2 \mathrm{~mm}$ ID, particle size of $4 \mu \mathrm{m}$ ) at the temperature of $30{ }^{\circ} \mathrm{C}$. The eluents were formed by mixing solvents $\mathrm{A}$ $\left(\mathrm{MeOH} / \mathrm{H}_{2} \mathrm{O}\right.$ in ratio of $\left.95: 5, \mathrm{v} \mathrm{v}^{-1}\right)$ and $\mathrm{B}\left(\mathrm{H}_{2} \mathrm{O}\right.$ ultrapure/formic acid $(0,1 \%)$ as follows: $1^{\text {st }}$ stage $-10 \%$ solvent $\mathrm{A}$ and $90 \% \mathrm{~B}$ (isocratic mode) for 5 minutes; $2^{\text {nd }}$ stage - linear gradient of solvents A and B (from 10 to $90 \%$ of A) for 2 minutes; $3^{\text {rd }}$ stage $90 \%$ solvent $\mathrm{A}$ and $10 \% \mathrm{~B}$ (isocratic mode) for 3 minutes; $4^{\text {th }}$ stage - linear gradient of solvents A and B (from 90 to $10 \%$ of A) for 7 minutes with a flow rate of $250 \mu \mathrm{L} \mathrm{min}{ }^{-1}$ of mobile phase. In all analyses, the injected volume was $5 \mathrm{uL}$ at a concentration of $300 \mathrm{mg} \mathrm{L}^{-1}$.

For the compounds identification, 76 standard phenolic compounds (3,4-dihydroxybenzoic acid, 4-aminobenzoic acid, 4hydroxybenzoic acid, 4-methyl-umbelliferone, acacetin, 4hydroxymethylbenzoic acid, $p$-anisic acid, caffeic acid, carnosic acid, cinnamic acid, chlorogenic acid, ellagic acid, ferulic acid, gallic acid, mandelic acid, methoxyphenylacetic acid, $o$-coumaric acid, $m$-coumaric acid, $p$-coumaric acid, rosmarinic acid, salicylic acid, sinapic acid, syringic acid, vanillic acid, apigenin-7-Oglucoside, apigenin, apigenin-7-O-rutinoside, apiine, aromadendrin, caffeic- $O$-hexoside acid, carnosol, catechin, chrysin, cirsimaritin, coniferaldehyde, coumarin, dicaffeoylquinic acid, epicatechin, epigallocatechin-gallate, epirosmanol, eriodictyol, scopoletin, fustin, galangin, gallocatechin, hydroxybenzoic- $O$-hexoside acid, hispidulin, isoquercetrin, isorhamnetin, isorhamnetin-3-O-hexoside, kaempferol, luteolin, luteolin-3'-O-glucuronide, luteolin-7-O-glucoside, luteolin-7-Orutinoside, medioresinol, metoxy carnosol, methyl carnosate, myricetrin, naringenin, naringin, poridzin, pinocembrin, protocatechuic acid, quercetin-3- $O$-hexoside, quercetin, resveratrol, rosmadial, rutin, sinapaldehyde, syringaldehyde, taxifolin, thymol, umbelliferone, vanillin and vitexin) diluted in methanol $\left(1 \mathrm{mg} \mathrm{L}^{-1}\right)$ were analysed in the same conditions as described above.

The liquid chromatograph was coupled to a mass spectrometer with electrospray ionization source using negative ionization mode with the following source parameters: ion spray interface at $400{ }^{\circ} \mathrm{C}$; ion spray voltage of $4500 \mathrm{~V}$; curtain gas, $10 \mathrm{psi}$; nebulizer gas, 45 psi; auxiliary gas, 45 psi; collision gas, medium. The Analyst ${ }^{\circledR}$ (version 1.5.1) software was used for recording and processing the data. Pairs of ions were monitored in MRM (Multiple Reaction Monitoring) mode.

\section{Evaluation of antibacterial activity Microorganisms and medium}

The Laboratory of Clinical Microbiology from FURB provided the bacterial strains. Tests were evaluated against Grampositive bacteria Staphylococcus aureus (ATCC 25923) and against Gram-negative bacteria Escherichia coli (ATCC 25922) and Pseudomonas aeruginosa (ATCC 27853). Mollicutes strains (no-cell-wall bacteria) Mycoplasma mycoides subsp. capri (NCTC 10137); Mycoplasma hominis (ATCC 33530), and Ureaplasma urealyticum (ATCC 27618) were also assessed. For the growth of bacterial strain, Müller-Hinton broth was used for S. aureus, S. E. coli and $P$. aeruginosa, U10 broth was used for U. urealyticum, SP4 broth to M. mycoides subsp. capri and M. hominis (Velleca et al., 1979). 


\section{Determination of minimum inhibitory concentration (MIC)}

The antibacterial activity of the crude extract and fractions from E. platysema was evaluated by determination of the minimum inhibitory concentration (MIC). The microdilution broth assay was performed in sterile 96-well microplates, as recommended by the Clinical and Laboratory Standards Institute (CLSI, 2012) for cell-wall bacteria and Bebear and Roberteson (1996) for mollicutes.

The samples were properly prepared and transferred to each microplate well with the appropriate culture medium, in order to obtain a twofold serial dilution of the original extract in a $10 \%$ $\mathrm{H}_{2} \mathrm{O}$ /dimethyl sulfoxide (DMSO) solution, obtaining sample concentrations ranging between $1000 \mu \mathrm{g} \mathrm{mL} \mathrm{m}^{-1}$ to $7.81 \mu \mathrm{g} \mathrm{mL} \mathrm{mL}^{-1}$. The inoculum containing $10^{4}$ to $10^{5}$ microorganisms per $\mathrm{mL}$ were then added to each well.

A number of wells were reserved in each plate to test for sterility control (no inoculum added), positive control (gentamycin or ciprofloxacin), inoculum viability (no extract added), and the DMSO inhibitory effect.

The microplates were incubated at $37{ }^{\circ} \mathrm{C} \pm 1{ }^{\circ} \mathrm{C}$ for 24 hours to cell-wall bacteria and 48 hours for mollicutes. Thereafter, growth of mollicutes strains was detected by observing the colour change in the medium. For cell-wall bacteria, a methanolic solution of triphenyl tetrazolium chloride $\left(5 \mathrm{mg} \mathrm{mL}^{-1}\right)$ was added into each well, and the presence of a reddish bacterial "button" observed at the bottom of each well. The MIC was defined as the lowest concentration of the sample able to inhibit bacterial growth.

\section{RESULTS AND DISCUSSION}

\section{Identification of phenolic compounds by HPLC-ESI-MS/MS}

Chemical profiling of 76 phenolic compounds from 5 samples using the HPLC-ESI-MS/MS method were carried out. The results are shown on Table 1. These results indicated that in the crude extract four phenolic compounds were identified: gallocatechin [2], syringic acid [3], salycilic acid [5] and isorhamnetin [7]. In the FDCM, syringic acid [3], 4hidroxycinammic acid [4], and luteolin [9] were identified. In the FAE salycilic acid [5], syringic acid [3], 4-hidroxycinammic acid [4] besides luteolin-3'-O-glucuronide [8] were also identified. In the $\mathrm{FBu}$, isoquercetin [6], salycilic acid [5], syringic acid [3] and 4-hidroxycinammic acid [4] were identified. The compounds hydroxybenzoic- $O$-hexoside acid [1], gallocatechin [2], salycilic acid [5], isoquercetin [6] and isorhamnetin [7] were identified in the aqueous fraction.

The skeletons of identified compounds are characteristics from the Eugenia genus (Baliga et al., 2010; Einbond et al., 2004; Oliveira et al., 2014). However, this is the first report of identification of salycilic acid and hydroxybenzoic- $O$-hexoside acid on leaves of Eugenia genus. Futhermore, this is the first report about the presence of these compounds in Eugenia platysema. The flavonoids isoquercetin and gallocatechin have been previously described in another plants of Eugenia genus, as E. brasiliensis (Pietrovski et al., 2008), E. jambolana (Baliga et al., 2011) and E. uniflora (Lee et al., 2000). Syringic acid were described in E. pyriformis and E. jambolana (Sharma et al., 2016); luteolin were identified in E. cariophyllata (Gülçin et al., 2004).

\section{Antibacterial Activity}

For the evaluation of the antibacterial activity, a criterion established by Machado et al., (2005), was used. Samples with MIC values lower than $10 \mu \mathrm{g} \mathrm{mL}^{-1}$ were considered to have excellent antibacterial activity; between 10 and $100 \mu \mathrm{g} \mathrm{mL}^{-1}$ were considered good; values between 100 and $500 \mu \mathrm{g} \mathrm{mL}$ were considered of moderate activity; values between 500 and 1,000 $\mu \mathrm{g}$ $\mathrm{mL}^{-1}$ of low activity, and for MIC values above $1,000 \mu \mathrm{g} \mathrm{mL}^{-1}$, samples were considered inactive. The results for MIC of all samples are shown in Table 2.

Table 1: Phenolic compounds identified in E. platysema by HPLC-ESI-MS/MS.

\begin{tabular}{|c|c|c|c|c|c|c|c|c|c|c|}
\hline & \multirow[t]{2}{*}{ Compound } & \multirow[t]{2}{*}{ Rt* (min) } & \multirow{2}{*}{$\begin{array}{c}\text { Calculated } \\
\text { Mass }\end{array}$} & \multirow{2}{*}{$\begin{array}{c}\text { Experimental mass } \\
{[\mathbf{M}-\mathbf{H}]}\end{array}$} & \multirow{2}{*}{$\begin{array}{c}\text { MS/MS } \\
(\mathrm{m} / z)\end{array}$} & \multicolumn{5}{|c|}{ Identified compounds } \\
\hline & & & & & & CHE & FDCM & FAE & FBu & FAq \\
\hline 1 & Hydroxybenzoic- $O$-hexoside acid & 7.85 & 299.80 & 299.07 & 137.00 & & & & & $\mathrm{x}$ \\
\hline 2 & Gallocatechin & 9.28 & 306.26 & 305.06 & 225.00 & $\mathrm{x}$ & & & & $\mathrm{x}$ \\
\hline 3 & Syringic acid & 9.69 & 198.17 & 196.86 & 119.60 & $\mathrm{x}$ & $\mathrm{x}$ & $\mathrm{x}$ & $\mathrm{x}$ & $\mathrm{x}$ \\
\hline 4 & 4-hydroxycinammic acid & 10.22 & 164.16 & 162.86 & 116.40 & & $\mathrm{x}$ & $\mathrm{x}$ & $\mathrm{x}$ & \\
\hline 5 & Salycilic acid & 10.58 & 138.12 & 136.85 & 90.11 & $\mathrm{x}$ & & $\mathrm{x}$ & & \\
\hline 6 & Isoquercetin & 10.73 & 464.38 & 462.90 & 297.30 & & & & $\mathrm{x}$ & $\mathrm{x}$ \\
\hline 7 & Isorhamnetin & 12.28 & 316.26 & 315.04 & 300.00 & $\mathrm{x}$ & & & $\mathrm{x}$ & $\mathrm{x}$ \\
\hline 8 & Luteolin-3'- $O$-glucuronide & 12.62 & 462.36 & 461.07 & 285.00 & & & $\mathrm{x}$ & & \\
\hline 9 & Luteolin & 13.24 & 286.24 & 285.03 & 267.00 & & $\mathrm{x}$ & & & \\
\hline
\end{tabular}

* $\mathrm{Rt}=$ retention time (minutes); $\mathrm{CHE}=$ crude hydroalcoholic extract; FDCM = Dichloromethane fraction; FAE = Ethyl acetate fraction; FBu = Butanolic fraction; $\mathrm{FAq}=$ Aqueous fraction.

Table 2. Antibacterial activity of crude extract and fractions from E. platysema.

\begin{tabular}{|c|c|c|c|c|c|c|}
\hline & \multicolumn{6}{|c|}{$\operatorname{MIC}^{\mathrm{a}}\left(\mu \mathrm{g} \mathrm{mL}^{-1}\right)$} \\
\hline & CHE & FDCM & FAE & FBu & FAq & Positive Control $^{\mathrm{b}}$ \\
\hline U. urealyticum & 125 & 125 & 500 & $>1000$ & $>1000$ & 40 \\
\hline M. mycoides subsp. capri & 250 & 125 & 250 & 500 & $>1000$ & 40 \\
\hline M. hominis & 250 & 125 & 250 & 500 & $>1000$ & 20 \\
\hline S. aureus & $>1000$ & $>1000$ & $>1000$ & $>1000$ & $>1000$ & 15.6 \\
\hline P. aeruginosa & $>1000$ & 1000 & 500 & $>1000$ & $>1000$ & 7.3 \\
\hline E. coli & $>1000$ & 1000 & 500 & $>1000$ & $>1000$ & 15.6 \\
\hline
\end{tabular}

${ }^{\mathrm{a}} \mathrm{MIC}=$ Minimal Inibitory Concentration. ${ }^{\mathrm{b}}$ Positive Control= ciprofloxacin, for mollicutes; gentamicin, for cel wall bacterials 
<smiles>[R2]c1cc(-c2oc3cc(O)cc(O)c3c(=O)c2[R])ccc1O</smiles><smiles>O=C(O)C=Cc1ccc(O)cc1</smiles>

[4]<smiles>[R]c1cc(C(=O)O)c([R])c([R])c1[R]</smiles>

$\begin{array}{ccccc} & \mathbf{R}_{\mathbf{1}} & \mathbf{R}_{\mathbf{2}} & \mathbf{R}_{\mathbf{3}} & \mathbf{R}_{\mathbf{4}} \\ \text { [1] } & \mathrm{H} & \mathrm{H} & \mathrm{O} \text {-glucose } & \mathrm{H} \\ \text { [3] } & \mathrm{H} & \mathrm{OCH}_{3} & \mathrm{OH} & \mathrm{OCH}_{3} \\ \text { [5] } & \mathrm{OH} & \mathrm{H} & \mathrm{H} & \mathrm{H}\end{array}$<smiles>O=C1c2c(O)cc(O)cc2O[C@H](c2cc(O)c(O)c(O)c2)[C@H]1O</smiles>

[2]

Fig. 1: Phenolic compounds identified in the leaves of Eugenia platysema.

Among the tested samples, the fractions which had the highest activity was FDCM against $U$. urealyticum, M. hominis and $M$. mycoides $\left(125 \mu \mathrm{g} \mathrm{mL}^{-1}\right)$ and FAE against $U$. urealyticum and M. mycoides subsp. capri $\left(125 \mu \mathrm{g} \mathrm{mL}^{-1}\right)$. The best activity of crude extract was against $U$. urealyticum $\left(125 \mu \mathrm{g} \mathrm{mL}^{-1}\right)$.

These results are important because the mollicutes are responsible for various diseases such as pneumonia, vaginitis, urethritis, and pyelonephritis in humans (Cordova et al., 2010). Reports of resistance to these microorganisms in conventional treatments also increased (Yechouron et al., 1992), in addition these microorganisms do not have cell wall, which makes them completely resistant to $\beta$-lactam antibiotics and other drugs that act on it (Silva, 2006). For the cell-wall bacteria none of samples tested were active, showing with MIC values above $1,000 \mu \mathrm{g} \mathrm{mL}$. This indicates that the mechanism of action of the extract and the fractions of E. platysema to inhibit bacterial growth is not involved with the bacterial cell wall.

Some of the identified phenolic compounds were report on literature to have antimicrobial properties. Luteolin, a wellknown polyphenolic compound identified in the dichloromethane fraction, has diverse biological benefits that include antimicrobial effects. Joung et al., (2016) reported that luteolin showed synergistic activity by increasing cytoplasmic membrane permeability and inhibiting ATPase. This is important on the effects of the membrane permeabilizing agent and ATP-binding cassette $(\mathrm{ABC})$ transporter inhibiting agent, since most bacteria produce $\mathrm{ABC}$ transporter that is an essential uptake system for amino acids in the bacterial membrane, and this mechanism can be a determinant of bacterial antibiotic resistance.
Other identified phenolic compounds like syringic acid has been reported to exhibit antibacterial ability against various microorganisms (Shi et al., 2016). The syringic acid retarded bacterial growth, and caused cell membrane dysfunction, with decrease of intracellular ATP concentration, cell membrane hyperpolarization and changes in cellular morphology (Shi et al., 2016).

However, this is the first study that evaluated the antibacterial activity of samples containing the syringic acid in its composition against mollicute strains. The presence of syringic acid and luteolin in the FDCM fraction probably contributes to the antibacterial potential of this fraction. These mechanisms may help to explain some of the good antibacterial activity shown by the dichloromethane fraction. However, further studies with the isolated compounds should be conducted, together with the identification of other classes of compounds, to searching for the responsible compounds for the antibacterial activity in these fractions and to better answer these questions.

\section{CONCLUSIONS}

Present results showed that nine phenolic compounds were identified in the extract and fractions from E. platysema. All of these compounds were reported the first time in this species. Interesting antibacterial activity for the extract and fractions of this species against mollicutes strains were observed, especially in the FDCM fraction. Further phytochemical studies should be performed to isolate and identify the active constituents for this activity. 


\section{ACKNOWLEDGMENTS}

The authors thank the FURB languages and Professor Luiz Henrique da Silva for the revision of the English language.

Financial support and sponsorship: The authors are also grateful to CAPES to the master fellowship support to Adrielli Tenfen and FURB to the financial support.

Conflict of Interests: The authors' declare no conflict of interest.

\section{REFERENCES}

Amirmozafari N, Mirnejad R, Kazemi B, Sariri E, Bojari MR, Darkahi FD. Comparison of polymerase chain reaction and culture for detection of genital mycoplasma in clinical samples from patients with genital infections. Saudi Med J, 2009; 30:1401-5.

Apel MA, Renata P Limberger, Sobral M, Henriques AH, Menut C, Bessiére J-M. Chemical Composition of the Essential Oils from Southern Brazilian Eugenia Species. Part III. J Essent Oil Res, 2002; 14:259-265.

Auricchio OI, Bacchi EM. Folhas de Eugenia uniflora L. (pitanga: propriedades farmacobotânicas, químicas e farmacológicas / Eugenia uniflora L. pitanga. Rev Adolf Lutz, 2003; 62:55-61.

Bag A, Bhattacharyya SK, Pal NK, Chattopadhyay RR. In vitro antibacterial potential of Eugenia jambolana seed extracts against multidrug-resistant human bacterial pathogens. Microbiol Res, 2002; 176:352-357.

Baliga MS, Bhat HP, Baliga BRV, Wilson R, Palatty PL. Phytochemistry, traditional uses and pharmacology of Eugenia jambolana Lam.(black plum): A review. Food Res Int, 2011; 44: 1776-1789.

Bayraktar MR, Ozerol IH, Gucluer N, Celik O. Prevalence and antibiotic susceptibility of Mycoplasma hominis and Ureaplasma urealyticum in pregnant women. Int J Infect Dis, 2010; 14:e90-5.

Bebear C, Roberteson J. 1996. Molecular and Diagnostic Procedures in Mycoplasmology. . 1st ed. San Diego: Academic Press.

Benfatti CS, Cordova SM, Guedes A, Magina MDA, Cordova CMM. Atividade antibacteriana in vitro de extratos brutos de espécies de Eugenia sp frente a cepas de molicutes. Rev Pan-Amazônica Saúde, 2010; $1: 33-40$.

CLSI. 2012. Performance Standards for Antimicrobial Susceptibility Testing: Twenty-Second Informational Supplement. Wayne, PA: Clinical and Laboratory Standards Institute, (M100-S22/ v. 32, n. 3).

Cordova SM de, Benfatti CS, Magina MDA, Guedes A, Cordova CMM. Evaluation of the antibacterial activity of extracts isolated from native plants of the Brazilian flora against Mycoplasma arginini, $M$. hominis and Ureaplasma urealyticum. Rev Brazileira Análises Clínicas, 2010; 42:241-244.

Einbond LS, Reynertson KA, Luo XD, Basile MJ, Kennelly EJ. Anthocyanin antioxidants from edible fruits Food Chem, 2004; 84:23-28.

Falk L, Fredlund H, Jensen JS. Signs and symptoms of urethritis and cervicitis among women with or without Mycoplasma genitalium or Chlamydia trachomatis infection. Sex Transm Infect, 2005; 81:73-8.

Famuyiwa F, Adebajo A. Larvicidal properties of Eugenia uniflora leaves. Agric Biol J North Am, 2012; 3:400-405.

Garmus TT, Paviani LC, Queiroga CL, Magalhaes PM, Cabral FA. 'Extraction of phenolic compounds from pitanga (Eugenia uniflora L.) leaves by sequential extraction in fixed bed extractor using supercritical CO2, ethanol and water as solvents. J Supercrit Fluids, 2014; 86:4-14.

Gülçin İ, Küfrevioğlu Öİ, Oktay M, Büyükokuroğlu ME. Antioxidant, antimicrobial, antiulcer and analgesic activities of nettle (Urtica dioica L.). J Ethnopharmacol, 2004; 90:205-215.

Joung D-K, Lee Y-S, Han S-H, Lee S-W, Cha S-W, Mun S-H, Kong R, Kang O-H, Song H-J, Shin D-W, Kwon D-Y. Potentiating activity of luteolin on membrane permeabilizing agent and ATPase inhibitor against methicillin-resistant Staphylococcus aureus. Asian Pac J Trop Med, 2016; 9:19-22.

Lee MH, Chiou JF, Yen KY, Yang LL. EBV DNA polymerase inhibition of tannins from Eugenia uniflora Cancer Lett, 2000; 154:131136.

Machado KE, Filho VC, Tessarolo ML, Mallmann C, MeyreSilva C, Bella-Cruz A. Potent Antibacterial Activity of Eugenia umbelliflora . Pharm Biol, 2005; 43:636-639.

Naessens A, Foulon W, Breynaert J, Lauwers S. Postpartum bacteremia and placental colonization with genital mycoplasmas and pregnancy outcome. Am J Obstet Gynecol, 1989; 160: 647-650.

Oliveira AL, Destandau E, Fougère L, Lafosse M. Isolation by pressurised fluid extraction (PFE) and identification using CPC and HPLC/ESI/MS of phenolic compounds from Brazilian cherry seeds (Eugenia uniflora L. Food Chem, 2014; 145:522-529.

Pietrovski EF, Magina MDA, Gomig F, Pietrovski CF, Micke GA, Barcellos M, Pizzolatti, MG, Cabrini DA,

Brighente IMC, Otuki MF. Topical anti-inflammatory activity of Eugenia brasiliensis Lam. (Myrtaceae) leaves J Pharm Pharmacol, 2008; 60:1-9.

Reitz RD., Legrand CD, Klein RM. 1969. Flora Ilustrada Catarinense. Herbário Barbosa Rodriguez, Itajaí.

Saha S, V. S. SE, Kodangala C, Mandal, CS, Shastry SC. Evaluation of antinociceptive and anti-inflammatory activities of extract and fractions of Eugenia jambolana root bark and isolation of phytoconstituents. Rev Bras Farmacogn, 2013; 23:651-661.

Shafaghat A, Pirfarshi F, Shafaghatlonbar M. Luteolin derivatives and antimicrobial activity of Achillea tenuifolia Lam. methanol extract. Ind Crops Prod, 2014; 62:533-536.

Sharma RJ, Gupta RC, Singh S, Bansal AK, Singh IP. Stability of anthocyanins- and anthocyanidins-enriched extracts, and formulations of fruit pulp of Eugenia jambolana ("jamun"). Food Chem, 2016;190:808-817.

Shi C, Sun Y, Zheng Z, Zhang X, Song K, Jia Z, Chen Y, Yang L, Liu X, Dong R, Xia X.Antimicrobial activity of syringic acid against Cronobacter sakazakii and its effect on cell membrane. Food Chem, 2016; 197:100-106.

Silva CHP.2006. Bacteriologia e micologia para o laboratório clínico. Rio de Janeiro : Revinter, c2006. 498 p, il.

Taylor BD, Darville T, Haggerty CL. Does bacterial vaginosis cause pelvic inflammatory disease? Sex Transm Dis, 2013; 40:117-22.

Tenfen A, Siebert DA, Yamanaka CN, Cordova MC, Scharf DR, Simionatto EL, Alberton MD. Chemical composition and evaluation of the antimicrobial activity of the essential oil from leaves of Eugenia platysema. Nat Prod Res, 2016; 30:2007-2011.

Velleca, W.M.; Bird B.R.; Forreste,r F.T; 1979. Laboratory diagnosis of Mycoplasma infections: course. Atlanta: U.S. Department of Health.

Victoria FN, Lenardão EJ, Savegnago L, Perin G, Jacob RG, Silva WP, Motta-Ade S, Nascente PS.

Essential oil of the leaves of Eugenia uniflora L.: Antioxidant and antimicrobial properties. Food Chem Toxicol, 2012; 50:2668-2674.

Yechouron A, Lefebvre J, Robson HG, Rose DL,Tully JG. Fatal Septicemia Due to Mycoplasma arginini: A New Human Zoonosis. Clin Infect Dis, 1992; 15:434-438.

How to cite this article:

Tenfen A, Siebert DA, Spudeit D, de Cordova CMM, Micke GA, Alberton MD. Determination of phenolic profile by HPLC-ESIMS/MS and antibacterial activity of Eugenia platysema against mollicutes strains. J App Pharm Sci, 2017; 7 (05): 007-011. 